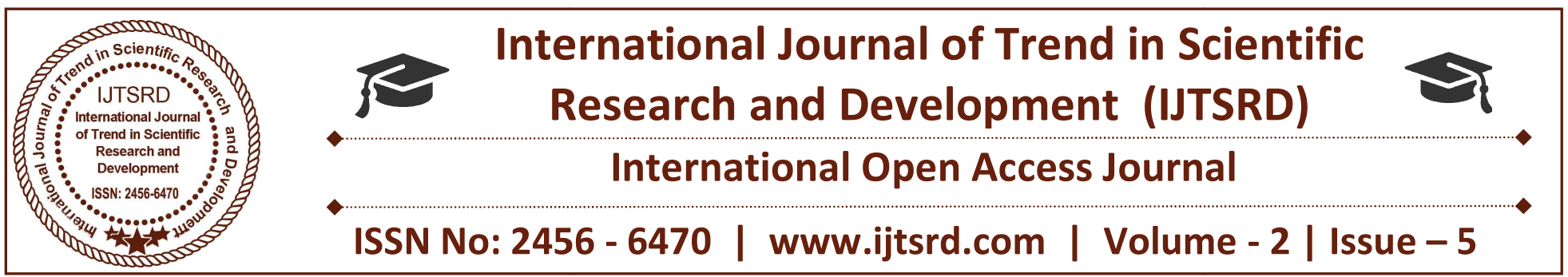

\title{
The Revolt of 1857 — The First War of Independence
}

\author{
Ankit Kumar Singh \\ B.A., L.L.B (Hons), Indore Institute of Law \\ Indore, Madhya Pradesh, India
}

By the first half of the 19th century, the East India Company had brought major portions of India under its control.

One hundred years after the Battle of Plassey, anger against the unjust and oppressive British Government took the form of a revolt that shook the very foundations of British rule in India.

While British historians called it the Sepoy Mutiny, Indian historians named it the Revolt of 1857 or the First War of Indian Independence. The Revolt of 1857 had been preceded by a series of disturbances in different parts of the country from the late eighteenth century onwards.

The Sanyasi Rebellion in North Bengal and the Chunar rebellion in Bihar and Bengal broke out in the late eighteenth century. There were several peasant uprisings in the mid- nineteenth century, the most important of which were those by the Moplah peasants of the Malabar and the Faraizi movement by Muslim peasants in Bengal.

The first half of the nineteenth century also witnessed a number of tribal revolts. In this context, mention may be made of the rebellions of the Bhils of Madhya Pradesh, the Santhals of Bihar and the Gonds and Khonds of Orissa. However, all these disturbances were localized. Although serious and, in some cases, long drawn, these did not pose any serious threat to the existence of the British Empire.

\section{Causes of the Revolt:}

\section{Political Causes:}

The political causes of the revolt may be traced to the British policy of expansion through the Doctrine of Lapse and direct annexation. A large number of
Indian rulers and chiefs were dislodged, thus arousing fear in the minds of other ruling families who apprehended a similar fate.

Rani Lakshmi Bai's adopted son was not permitted to sit on the throne of Jhansi. Satara, Nagpur and Jhansi were annexed under the Doctrine of Lapse. Jaitpur, Sambalpur and Udaipur were also annexed. Other rulers feared that the annexation of their states was only a matter of time. The refusal to continue the pension of Nana Saheb, the adopted son of Baji Rao II, created hostility among the ruling class. ${ }^{1}$

Moreover, the sentiments of the people were hurt when it was declared that the descendants of the titular Mughal Emperor, Bahadur Shah II, would not be allowed to live in the Red Fort. The annexation of Awadh by Lord Dalhousie on the pretext of maladministration left thousands of nobles, officials, retainers and soldiers jobless. This measure converted Awadh, a loyal state, into a hotbed of discontent and intrigue.

\section{Social and Religious Causes:}

A large section of the population was alarmed by the rapid spread of Western civilization in India. An Act in 1850 changed the Hindu law of inheritance enabling a Hindu who had converted into Christianity to inherit his ancestral properties. Besides, the missionaries were allowed to make conversions to Christianity all over India. The people were convinced that the Government was planning to convert Indians to Christianity.

\footnotetext{
${ }^{1}$ Eric Strokes, Cristopher and Alan balayl, The peasant armed: the Indian revolt of 1857, $\left(1986,3^{\text {rd }}\right.$ Edition $), 221$
} 
The abolition of practices like sati and female infanticide, and the legislation legalizing widow remarriage, were threats to the established social structure.Even the introduction of the railways and telegraph was viewed with suspicion.

\section{Economic Causes:}

In rural areas, peasants and zamindars resented the heavy taxes on land and the stringent methods of revenue collection followed by the Company. Many among these groups were unable to meet the heavy revenue demands and repay their loans to money lenders, eventually losing the lands that they had held for generations. ${ }^{2}$ Large numbers of sepoys were drawn from the peasantry and had family ties in villages, so the grievances of the peasants also affected them.

The economic exploitation by the British and the complete destruction of the traditional economic structure caused widespread resentment among all sections of the people. After the Industrial Revolution in England, there was an influx of British manufactured goods into India which ruined industries, particularly the textile industry, of India.

Indian handicraft industries had to compete with cheap machine- made goods from Britain. India was transformed into a supplier of raw materials and a consumer of goods manufactured in Britain. All those people who previously depended on royal patronage for their livelihoods were rendered unemployed. So they bore a deep- seated grievance against the British.

\section{Military Causes:}

The Revolt of 1857 started as a sepoy mutiny. It was only later on that other elements of society joined the revolt.

Indian sepoys formed more than $87 \%$ of British troops in India. They were considered inferior to British soldiers. An Indian sepoy was paid less than a European sepoy of the same rank. Besides, an Indian sepoy could not rise to a rank higher than that of a Subedar. ${ }^{3}$

The extension of the British Empire in India had adversely affected the service conditions of Indian sepoys. They were required to serve in areas far away

\section{${ }^{2}$ ibid}

${ }^{3}$ Rudrangshu Mukheriee, Awadh in Revolt, 1857-1858: A Study of Popular Resistance,2002 $1^{\text {st }}$ Edition , 196 from their homes. In 1856 Lord Canning issued the General Services Enlistment Act which required that the sepoys must be ready to serve even in British land across the sea.

The 'Bengal Army' was recruited from high caste communities in Awadh. They were not prepared to cross the ocean (Kalapani) which was forbidden as per Hindu religious beliefs. They developed the suspicion that the Government was trying to convert Indians to Christianity.After the annexation of Awadh the Nawab's army was disbanded. These soldiers lost their means of livelihood. They became bitter enemies of the British.

\section{Immediate Cause:}

The Revolt of 1857 eventually broke out over the incident of greased cartridges. A rumour spread that the cartridges of the new Enfield rifles were greased with the fat of cows and pigs. Before loading these rifles the sepoys had to bite off the paper on the cartridges. Both Hindu and Muslim sepoys refused to use them. Canning tried to make amends for the error and the offending cartridges were withdrawn, but by then the damage had been done. There was unrest in several places.

In March 1857, Mangal Pandey, a sepoy in Barrackpore, had refused to use the cartridge and attacked his senior officers. He was hanged to death on 8th April. On 9th May, 85 soldiers in Meerut refused to use the new rifle and were sentenced to ten years' imprisonment. 
Different leaders Associated with the Revolt of 1857

\begin{tabular}{|l|l|}
\hline Barrackpore & Mangal Pandey \\
\hline Delhi & Bahadur Shah II, General Bakht Khan \\
\hline Delhi & Hakim Ahsanullah (Chief advisor to Bahadur Shah II) \\
\hline Lucknow & Begum Hazrat Mahal, Birjis Qadir, Ahmadullah (advisor of the ex-Nawab of Awadh) \\
\hline Kanpur & Nana Sahib, Rao Sahib (nephew of Nana), Tantia Tope, Azimullah Khan (advisor of \\
Nana Sahib)
\end{tabular}

\section{Main events of the revolt:}

Soon there was a rebellion in the Meerut Cantonment. The Meerut Mutiny (May 9, 1857) marked the beginning of the Revolt of 1857. The Indian sepoys in Meerut murdered their British officers and broke open the jail. On May 10, they marched to Delhi.

\section{Capture of Delhi:}

In Delhi the mutineers were joined by the Delhi sepoys and the city came under their control. Next day, on 11th May, the sepoys proclaimed the ageing Bahadur Shah Zafar the Emperor of Hindustan. But Bahadur Shah was old and he could not give able leadership to the sepoys. The occupation of Delhi was short-lived.

\section{Fall of Delhi:}

The British finally attacked Delhi in September. For six days there was desperate fighting. But by September 1857, the British reoccupied Delhi. Thousands of innocent people were massacred and hundreds were hanged. The old king was captured and later deported to Rangoon where he died in 1862. His sons were shot dead. Thus ended the imperial dynasty of the Mughals.

\section{Centres of the revolt:}

The revolt spread over the entire area from the neighbourhood of Patna to the borders of Rajasthan. There were six main centres of revolt in these regions namely Kanpur, Lucknow, Bareilly, Jhansi, Gwalior and Arah in Bihar.

\section{Lucknow:}

Lucknow was the capital of Awadh. There the mutinous sepoys were joined by the disbanded soldiers from the old Awadh army. Begum Hazrat Mahal, one of the begums of the ex-king of Awadh, took up the leadership of the revolt. Finally the British forces captured Lucknow. The queen escaped to Nepal.

\section{Kanpur:}

In Kanpur the revolt was led by Nana Saheb, the adopted son of Peshwa Baji Rao II. He joined the revolt primarily because he was deprived of his pension by the British. He captured Kanpur and proclaimed himself the Peshwa. The victory was short- lived.

Kanpur was recaptured by the British after fresh reinforcements arrived. The revolt was suppressed 
with terrible vengeance. The rebels were either hanged or blown to pieces by canons. Nana Saheb escaped. But his brilliant commander Tantia Tope continued the struggle. Tantia Tope was finally defeated, arrested and hanged.

\section{Jhansi:}

In Jhansi, the twenty-two-year-old Rani Lakshmi Bai led the rebels when the British refused to accept the claim of her adopted son to the throne of Jhansi. She fought gallantly against the British forces. But she was ultimately defeated by the English.

Rani Lakshmi Bai escaped. Later on, the Rani was joined by Tantia Tope and together they marched to Gwalior and captured it. Sindhia, a loyal ally of the British, was driven out. Fierce fighting followed. The Rani of Jhansi fought like a tigress. She died, fighting to the very end. Gwalior was recaptured by the British.

\section{Bihar:}

In Bihar the revolt was led by Kunwar Singh.

\section{Causes of the failure of the revolt:}

\section{Limited Uprising:}

Although the revolt was fairly widespread, a large part of the country remained unaffected by it. The revolt was mainly confined to the Doab region. Sind, Rajputana, Kashmir, most parts of Punjab. The southern provinces did not take part in it. It failed to have the character of an all-India struggle.Important rulers like Sindhia, Holkar, Rana of Jodhpur and others did not support the rebels. ${ }^{4}$

\section{No Effective Leaders:}

The rebels lacked an effective leader. Nana Saheb, Tantia Tope and Rani Lakshmi Bai were brave leaders, no doubt, but they could not offer effective leadership to the movement as a whole.

\section{Limited Resources:}

The rebels lacked resources in terms of men and money. The English, on the other hand, received a steady supply of men, money and arms in India.

\section{No Participation of the Middle Class:}

The English educated middle class, the rich merchants, traders and zamindars of Bengal helped the British to suppress the revolt.

\section{Results of the revolt:}

The great uprising of 1857 was an important landmark in the history of modern India. The revolt marked the end of the East India Company's rule in India. India now came under the direct rule of the British Crown. This was announced by Lord Canning at a Durbar in Allahabad in aproclamation issued on 1 November 1858 in the name of the Queen. ${ }^{5}$ Thus, Indian administration was taken over by Queen Victoria, which, in effect, meant the British Parliament. The Governor General's office was replaced by that of the Viceroy.

The Doctrine of Lapse was abolished. The right to adopt sons as legal heirs was accepted. The Revolt of 1857 paved the way for the future struggle for freedom in India.

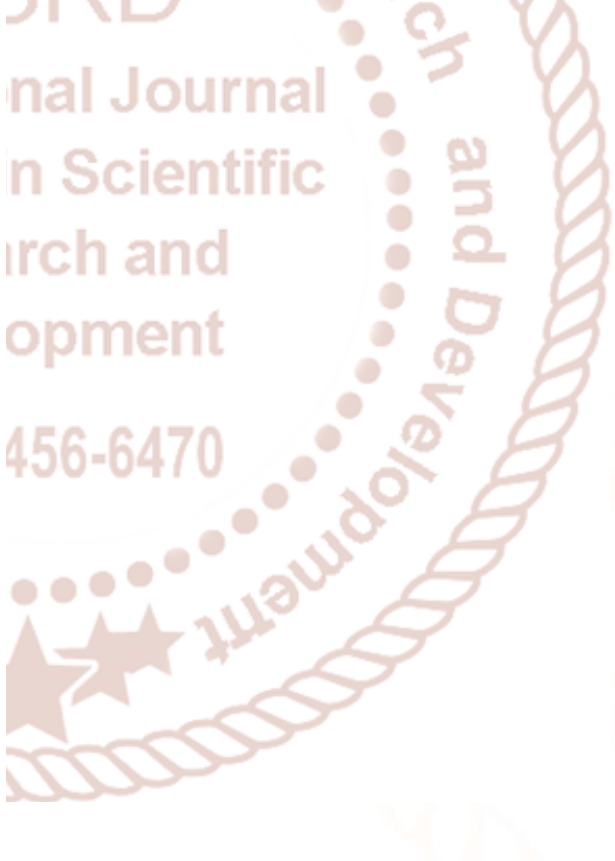

${ }^{4}$ Pratap Singh Mukharya, The Revolt of 1857: Saugor and Nerbudda Territories, $20011^{\text {st }}$ edition, 120 